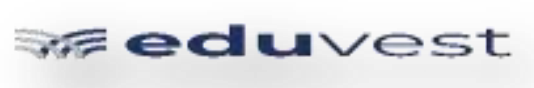

Eduvest - Journal of Universal Studies

Volume 2 Number 2, February 2022

p- ISSN 2775-3735 e-ISSN 2775-3727

\title{
NON-FORMAL EDUCATION MODEL IN BUILDING STUDENT CHARACTER IN MATARAM WEST NUSA TENGGARA INDONESIA
}

\author{
I Nyoman Wijana, Ni Putu Listiawati, Ni Luh Drajati Ekaningtyas \\ State Hindu Institute Gde Pudja Mataram, Indonesia \\ Email: wijanainyoman11@gmail.com,dhyanawilis@yahoo.com, \\ drajatieka@gmail.com
}

\begin{tabular}{|c|c|}
\hline ARTICLE INFO & ABSTRACT \\
\hline $\begin{array}{l}\text { Received: } \\
\text { January, } 26^{\text {th }} \\
2022 \\
\text { Revised: } \\
\text { February, 17th } \\
2022 \\
\text { Approved: } \\
\text { February, } 18^{\text {th }} \\
2022\end{array}$ & $\begin{array}{l}\text { This study aims to explore, analyze, and describe the non- } \\
\text { formal pasraman education model in building the character } \\
\text { of students in Mataram City, West Nusa Tenggara } \\
\text { Indonesia. The research was conducted in non-formal } \\
\text { Pasramans in Mataram City, using a qualitative method. } \\
\text { The results of this study indicate that, non-formal pasraman } \\
\text { as an educational institution has a role; (1) as a forum for } \\
\text { deepening religious education, especially Hindu religious } \\
\text { practices, in order to shape the habits and character of } \\
\text { students, (2) to prepare and foster achievements in the } \\
\text { Hindu religious field, as the basis for building self- } \\
\text { confidence, (3) to shape and foster character religious } \\
\text { students, (4) fostering a sense of brotherhood and } \\
\text { communication between students, with the implementation } \\
\text { of the teachings of Tri Hita Karana, as the basis for building } \\
\text { the character of tolerance, cleanliness, and discipline, (5) as } \\
\text { a medium for moral and ethical formation, in building the } \\
\text { character of decency. Based on qualitative data analysis, it } \\
\text { shows that the urgency of non-formal pasraman education } \\
\text { is so important to shape the character of students, for that } \\
\text { it is recommended that pasraman managers continuously } \\
\text { improve the quality of learning, and in their management } \\
\text { they should use professional management. }\end{array}$ \\
\hline \multirow[t]{2}{*}{ KEYWORDS } & Education, Non-Formal Pasraman, Character Formation \\
\hline & $\begin{array}{l}\text { I Nyoman Wijana, Ni Putu Listiawati, Ni Luh Drajati Ekaningtyas. } \\
\text { (2022). Non-Formal Education Model in Building Student Character } \\
\text { in Mataram West Nusa Tenggara Indonesia. Journal Eduvest. Vol } \\
\text { 2(2): } 306-316 \\
2775-3727 \\
\text { https://greenpublisher.id/ }\end{array}$ \\
\hline
\end{tabular}




\begin{tabular}{ll}
\hline cc) (i) () & This work is licensed under a Creative Commons \\
Attribution-ShareAlike 4.0 International
\end{tabular}

\section{INTRODUCTION}

Education as one of the media to build a complete human being, becomes the front line in building the character of the nation's generation (Agus, Cahyanti, Widodo, Yulia, \& Rochmiyati, 2020). Education covers a very wide space; because in it there are various educational centers; namely formal education which is carried out with the school system, there is also informal education carried out in the family, as well as non-formal education which is carried out through course institutions, trainings, and other non-formal educational institutions.

Pasraman is one of the educational institutions in Hinduism. Pasraman can be in the form of formal educational institutions, and some are in the form of non-formal educational institutions (Sutriyanti \& Dharmawan, 2022). The establishment of a nonformal boarding school in Indonesia, at the beginning of its history, could be said to be a solution for Hindu students who did not receive religious education in formal schools (Leganger-Krogstad, 2021). Later it developed into a need for Hindu children to learn more about knowledge and skills related to Hinduism, even though in their respective schools they have received religious lessons.

Religious lessons in schools are only in the form of knowledge as contained in the curriculum, while children in the process of character building require noble values that are internalized through the educational process and through the process of imitating their environment. According to the view of Behaviorism, humans do not bring talent from birth, but are shaped by the surrounding environment that provides values, which will shape a person's character (Akbar \& Sulkifli, 2021). Humans do not bring talent when they are born, but humans will develop and determine their own psyche based on the stimulus received from their environment.

Non-Formal Pasraman is an educational institution formed to be able to provide a stimulus to students, the younger generation of Hindus, in building character based on religious values, which is implemented in activities based on religious culture, as well as local wisdom traditions.

The phenomenon that has occurred in the city of Mataram related to non-formal pasraman lately, it is clear that the expectations of the community to educate their children who are still of school age (elementary school, junior high school, and high school) in order to get religious education in pasraman are increasing. enthusiastic. Preliminary observations carried out in several pasramans in the city of Mataram, information can be obtained that parents of students want their children to acquire knowledge and skills related to the religion they believe in. Meanwhile, the information obtained from the students stated that religious lessons at school were only memorizing religious theories, while the practice was very little so that it was inadequate to be applied in everyday life at home and in society.

In addition, parents' concerns about the influence of information technology which is very free, as well as the influence of young people's association which is getting further away from polite attitudes, respect for parents is fading, and other negative influences, require a filter that is coaching by internalizing values (Alief \& Nashruddin, 2022) noble, one of which can be done in the non-formal pasraman (Arnyana \& Utami, 2021).

Based on these various views and ideas, it inspires that research in the field of non-formal pasraman education in shaping the character of Hindu students is interesting 
to be done seriously, using the scientific method (Wardhani, Yuliastanti, \& Mahardhika, n.d.). Thus, the author wants to examine more deeply the Hindu education model in the form of non-formal Pasraman, and how its role is in shaping the character of Hindu students in the city of Mataram, in taking part in building the character of the younger generation of Hindus, as part of the nation's generation.

\section{RESEARCH METHOD}

This study uses a qualitative method. The use of qualitative methods is intended to reveal, analyze, and describe the non-formal pasraman model of education in shaping the character of students in the city of Mataram, the problems faced, and its role in the implementation of value education for the development of the character and morals of the younger generation of Hindus in the city of Mataram. This research was conducted at non-formal pasraman education in Mataram City (Suardana, Jelantik, Widaswara, \& Harnika, 2021).

Determination of informants is done purposively. Primary data were obtained from the Head of Pasraman, teachers, administrative staff, parents, and students (DIVAYANA, 2018) Determination of informants like this aims to obtain adequate information about the role of non-formal pasraman education in building the character of the students (Arta, 2020). The main instrument used was the researcher himself, and was assisted by a recording device used during interviews, a camera to take pictures, and field notes

Data collection using techniques; interviews, observations, and documentation techniques (Natow, 2020). The data obtained in this study are in the form of words, sentences, or paragraphs expressed in narrative form, which are descriptive of situations, events, interactions, statements and behaviors of the research subjects as written in interview transcripts or field notes (Mohajan, 2018). Based on the form and properties of the data, the data analysis technique used in this research is a descriptive technique which is carried out through three activity lines, namely; data reduction, data presentation, and conclusion drawing. (Rumkel, Sam, \& Umanailo, 2019).

\section{RESULT AND DISCUSSION}

Based on the results of observations during the preliminary study, it was found that the number of Pasraman as a model of non-formal pasraman education in Mataram City was 8 Pasraman (Suwardani, n.d.). The names of the Pasraman are; Pasraman Sad Dharma Dwijendra, Pasraman Dharma Putra, Pasraman Swasta Pranawa, Pasraman Varitra Saraswati, Pasraman Saraswati, Pasraman Samiaga, Pasraman Eka Dharma, and Pasraman Widya Dharma Santih.

The various activities carried out by each pasraman in Mataram City, according to the data obtained at the research site, have the same types of activities, although there are differences between one pasraman and another, but not so prominent. The activities carried out after being identified consist of; deepening of Hindu religious education materials, dance coaching activities, Balinese script learning, Dewanagari letter learning, Yoga Asanas activities, ritual lessons, Dharma Gita activities, musical activities (percussion arts), Japanese language learning, English, computer learning, pasraman jamboree, and sport. 


\section{Nyoman Wijana, Ni Putu Listiawati, Ni Luh Drajati Ekaningtyas}

The learning method used to deliver various materials in teaching and learning activities at the Pasraman is a Hindu teaching method called Sad Dharma; (1) Dharma Tula (2) Dharma Wacana (3) Dharma Gita (4) Dharma Yatra (5) Dharma Sadhana (6) Dharma Santi.

Dharma Tula; this method is a learning method in Hinduism by way of discussion (Sutriyanti, Marsono, \& Supandi, 2019) Dharma Wacana; This method is a learning method in Hinduism by delivering certain material in front of participants by means of a monologue. Dharma Gita; This method is a learning method in Hinduism, by reading Hindu holy books with singing techniques. Dharma Yatras; This method is a method of learning Hinduism, by practicing religious activities by directly visiting holy places, to pray together with all pasraman students, and the coaches. Dharma Sadhana; this learning method is a learning method in Hinduism which is carried out by realizing the teachings of Hinduism with Catur Marga Yoga which consists of; Bhakti Marga is the realization of religious teachings by doing devotional service or worship to Ida Hyang Widhi, Karma Marga is realizing religious teachings by working sincerely and professionally in their respective fields, Jnana Marga is realizing Hindu religious teachings by studying science to be devoted on the road dharma, and Raja Marga Yoga, namely realizing the teachings of Hinduism by carrying out the path of Yoga and meditation

Dharma Santi; is a learning method in Hinduism by establishing good communication with fellow Hindus in particular and fellow human beings in general (Anggreni, n.d.) Dharma santi can be used as a method to build social sensitivity to pasraman students.

Characters in the Hindu perspective are essentially human traits based on the value of Tri Kaya Parisudha, reflected in ways of thinking (manacika), ways of communicating through words (wacika) and actions (kayika) that are in accordance with religious rules.

The non-formal pasraman education model can contribute to building the character of the younger generation of Hindus. Based on interviews conducted by researchers with several pasraman administrators and also parents who had been met at the research location, they explained several roles that non-formal pasraman could play in building student character, namely;

\section{Building Student Character By Deepening Religious Education}

In connection with the phenomenon of the nation's moral degradation, parents of students and observers of education, especially Hindu religious education, and supported by religious leaders, community leaders, and educational figures, are very enthusiastic to establish a non-formal educational institution in the form of the pasraman. Basically, their goal is the same, namely to provide a platform for their children to receive additional religious education, especially those related to Hindu religious practices which are simple but very important in building their habits and character in the future.

Theoretically, it can be traced through John Locke's theory of empiricism, which explains that humans are born like white paper, experience is then written on the white paper, which will shape a person's character, whether to be a good character or a bad character. If we refer to this theory, then a person's character can be formed through experience in the context of this research through education, especially non-formal pasraman education. 
Indeed, John Lock's idea is different from the theory put forward by Lombrosso and Schopenhouer with the theory of Nativism. This theory explains that a person's character is innate from birth, and cannot be changed through education. If we rely on this theory, character education that is carried out with the intention of making changes to one's character is just a futile job. Bridging the conflicting ideas with each other, the Convergence theory emerged which was pioneered by William Stren, which explains that a person's character is not only innate from birth, but is also influenced by the environment through education. This theory can clearly be understood that a person's character can be formed through education, in order to create human beings with good character in a country, including Indonesia.

Based on various opinions and arguments about the importance of character education, and supported by empirical facts about the occurrence of various phenomena that show the nation's moral decadence, character education is echoed in almost all veins of educational institutions, both formal, informal, and non-formal. Hindus take part in building the character of the younger generation of Hindus through pasraman forums.

Hindu religious education for children at Elementary School, Junior High School, Senior High School, and Vocational High School has been given in their respective schools in accordance with the established curriculum. However, Hindu religious education provided in schools is not enough to equip students to understand their religion in depth. They are enthusiastic about participating in the activities at the Paritra Saraswati boarding school, especially when they are taught yoga asanas, because at school they can only skim according to the curriculum, while at the pasraman they practice directly, and the coaches explain the meaning of all the movements.

Learning aspects of Hinduism in pasraman tends to be more in-depth than studying religion in their respective schools. This is due to the very limited availability of time to deepen something at school, while teachers have to discuss many things according to what is outlined in the curriculum. While in Pasraman, you can study something in particular, because in one day you only learn one thing, for example in the 3rd week only yoga asanas, the other week only Dharma Gita, and so on. All learning activities are related to the formation of student character.

\section{Building Confidence Character by Fostering Achievements in the Religious Field}

Preparing and fostering pasraman children to have non-academic achievements, especially in Hindu religious competitions, is not just a dream for pasraman administrators. One of the pasraman students who had graduated at the high school level said that Dwijendra pasraman students had won competitions for Hindu religious activities, both at the national, provincial and city levels of Mataram. The champions that have been won include; 1 st place in the yoga asanas competition at the Utsawa Dharma Gita at the National Level, 1st place in the memorizing competition for the most verses at the Utsawa Dharma Gita at the provincial level, and 3rd place in the Palawakya for male teenagers at the Mataram City level.

When interviewed with the coaching teachers at the Private Pasraman, Pranawa also told things related to the achievements of the Pasraman students. In 2016 pasraman students were able to represent NTB in the pasraman jamboree at the national level which was held in Yogyakarta. The fields of competition represented include; mekidung competitions, yoga asanas competitions, religious poetry reading, palawakya competitions, and five prayer competitions. In this activity, the Pranawa private pasraman 
students won the Panca Worship competition by getting 1st place, and also won the religious poetry competition by getting 2 nd place.

Based on the data obtained regarding the various achievements that the pasraman students make proud, both at the Dwijendra pasraman and the Pranawa private pasraman students, the role contributed by the pasraman in building the character of the Hindu youth generation is quite appropriate as a medium for coaching and fostering nonacademic student achievement. This is related to building self-confidence in students.

In the process of fostering Yoga achievement, for example, students are trained together to do yoga asanas. To prepare students to have certain achievements, the coach can choose students who are ready to be fostered further. In this way, the children of Pasraman students tend to be able to achieve achievements in non-academic competitions organized by the Regional Office of the Ministry of Religion at the City, Provincial level, as well as those held at the national level by the Directorate General of Hindu Guidance.

Pasraman students are given Yoga Asanas practice, this exercise is not only aimed at improving religious character, patience, honesty, calmness, for the participants, it is also intended to find seeds that will be nurtured to have achievements in the field of Yoga Asanas, which are always contested at events- certain events both at the Regency/City level, Province, and National level.

In addition, Pasraman students are also given training in their playing skills, using the Balinese version of the gamelan instrument, this is intended to foster a love for cultural wisdom, also to prepare students who have the potential to be fostered further, in order to achieve the achievements in the competition.

There are several activities that are usually contested at the pasraman jombore event, including; (1) the Tri Sandhya mantram competition which is participated by male/female elementary school (SD) students (2) the prayer kramaning competition participated by male/female junior high school (SMP) students, (3) male and female pasraman competitions daily prayer recitation followed by pasraman students at the junior high school (SMP), and high school (SMA) and vocational high school (SMK) male/female levels, (4) Hindu religious song creation competition participated by students male/female high school (SMA) and vocational high school (SMK) students, (5) writing and reading competitions for Hindu religious poetry followed by pasraman students at junior high school (SMP) level, high school level ( SMA) and Vocational High School (SMK) male/female, (6) Hindu religious storytelling competition followed by elementary school (SD) students, male/female, (7) Yoga Asanas competition followed by pasraman students Junior High School (SMP), ti High School/Vocational High School (SMA/SMK) level in male/female groups.

All types of competitions, the participants from various pasraman, and prepared systematically by each pasraman with the help of the trainers. In the learning process in preparing the best participants, the theory of connectionism pioneered by Thorndike applies with three main laws, namely; law of exercise, law of effect, and law of readiness.

\section{Forming and Fostering Students' Religious Character}

Non-formal Pasraman also has a role to shape and foster the religious character of students. This is done through activities in the form of religious practices. All of the 
pasramans studied showed that before starting a certain activity at the weekly meeting, it was preceded by praying together at their respective pasraman locations. This joint prayer activity is always carried out so that pasraman students make prayer activities a habit, so that over time it will become a culture, and after that it will become a character.

A good education is not only measured by cognitive abilities. In other words, a child is educated not only to be smart but also to be good. So that children who have received education can become smart and good, then what is developed includes intellectual factors, as well as religious intelligence factors. Their intellectual intelligence has been fully developed in their respective formal schools, while pasramans can develop their religious intelligence or religious intelligence.

Changes in the behavior of children who previously did not want to regularly pray, and then after being accustomed to the pasraman there was a positive change, and they wanted to carry out prayer activities at their respective homes before going to school. This change in behavior is in line with the Behaviorism theory which holds that in reality humans do not bring their mental talents from birth, because humans will develop and determine their own psyche based on the stimulus received from their environment. Thus, human character is actually formed based on the response received to the stimulus from the environment. If the environment is good then a human child will grow up to be a good human being, and vice versa if the environment is bad, then a child will grow up to be a child with bad character.

Non-formal Pasraman as a Hindu educational institution, is a good environment, which was established by the community as a contribution to contribute to their country, in an effort to build the nation's character. No matter how small a donation is given for good, it will gradually grow into the next good. The learning experiences provided in the hostels are very thick with learning experiences related to religion. The various activities fostered by the pasraman teachers are a stimulus, a good example that can be imitated by students, for example how to say greetings properly, and of course also explain what the meaning of the greetings is. From the imitation of the pasraman students on the stimulus provided by the coaches, it can have implications for behavioral changes for these children. Changes in behavior that occur in a positive direction if you continue to be used to it will become character.

The religious character of a pasraman student can be seen from the behavior shown by the level of sradha and devotional service. To assess the good behavior of Sradha and Bhati, of course, it can be seen from their prayer activities, it can also be seen from the way they speak, which is done in a friendly, polite, and courteous manner, respects the coaches, and does not say harsh words, both to the teacher and to the teacher. to his friends. If such behavior can be accustomed, then all students have developed their religious character, which in Hinduism can be based on Tri Kaya Parisudha, namely three purified behaviors; (1) manacika; it means good and right thinking, (2) wacika; speak good and right words, and (3) kayika behaves well and correctly. The character of Tri Kaya Parisudha is a very basic and main religious character in Hinduism, because the three behaviors will affect the other characters.

Worship with the pasraman children is not only routinely held at the time of the activity schedule every Sunday, before the activity begins, but is also held on certain days if there are activities involving pasraman children such as; piodalan day at the temple where the pasraman is located, as well as ngayah or mutual cooperation activities to clean the temple area. 
All pasraman students are gathered in the main mandala of the temple, to pray together, given examples by the coaches then followed by all students. This is done every Sunday, on the pasraman activity schedule and is carried out before the main activity resumes.

In addition to prayer activities, Pasraman's efforts to grow and foster religious character are also carried out with various other activities, such as; the practice includes simple upakara facilities, yoga asanas, dance exercises, drumming exercises, and other activities.

In addition, Pasraman students are also given the skills to make simple ceremonial materials/facilities, such as making kelangsah/woven made from old coconut leaves. These activities are dedicated to improving the skills of pasraman students, as well as to improving their religious character, because all the equipment they make can be used for religious ceremonies, which have symbolic meanings.

\section{Building a Tolerant, Clean, and Disciplined Character}

Pasraman can play a role in fostering a sense of brotherhood among Hindu students who come from different schools. With the activities carried out at the pasraman they are met every week, and they can establish communication with one another, so that over time friendship and brotherhood are established.

Communication and brotherhood that are built through pasraman activities are a process of habituation in a real social space. Each meeting the students will see for themselves how the examples given by the coaches, such as; how to say hello every time you meet other coaches, between students and coaches, between students and students, and between coaches and coaches. Salam is a simple greeting, but greetings in Hinduism contain prayers, which are intended for the good of others as well as the good of oneself. This kindness must be continuously accustomed through the media of communication with fellow Pasraman residents, so that it can become a habit for them.

In pasraman activities, they are taught how to work together, and help each other, both in doing group tasks related to learning activities, as well as in tasks to keep the pasraman environment clean. Cooperating and working together in cleaning the pasraman area related to the implementation of the Tri Hita Karana concept in Hinduism. Tri Hita Karana means; three causes of happiness in human life, namely; (1) parhyangan; good and harmonious relationship between man and God, (2) pawongan; harmonious relationship between humans and humans, and (3) palemahan; maintain a harmonious relationship with the natural environment.

Maintaining a harmonious relationship with God can grow one's religious character. Meanwhile, maintaining a harmonious relationship between humans and fellow human beings fosters communication and brotherhood, as well as the character of honesty, compassion, and sincere empathy for others. Maintaining a harmonious relationship between humans and the natural environment can foster a clean and disciplined character.

The role of Pasraman in fostering brotherhood and establishing communication among fellow Pasraman residents is in line with Watson's behavioristic theory, which explains that the formation of human character requires a conditioned environment to influence a person to behave as expected. Watson does not believe in the character he is born with. A person will be good, when he is and hangs out in a good environment, and vice versa someone will behave badly if he is and hangs out in a bad environment 
continuously, so that it becomes a habit, then the habit lasts for a long time will become a culture, and so on. certainly will become a person's character.

In addition to establishing communication and brotherhood, Tirta Yatra's activities are also able to foster religious character for pasraman students. In practice they are fostered by their teachers, and at the place of prayer they can learn about the history of each temple, and can get an explanation of the ceremonial means used, and the meaning of each of these facilities. This can be accustomed so that it becomes a culture for all pasramans, in order to cultivate the noble character of the younger generation, especially the younger generation of Hindus. Mutual cooperation activities in the context of cleaning the pasraman environment. This activity is an implementation of the teachings of Tri Hita Karana, namely; in terms of weakness by maintaining a harmonious relationship between humans and the natural environment.

\section{As a Media for Moral and Ethical Formation}

Pasraman can act as a medium for moral and ethical formation of students. The activities carried out are very close to the development of moral values, and ethical values in Hinduism. The formation of morals and ethics is a complicated thing. A person's failure to deal with the moral problems he faces in everyday life is generally a matter of awareness, that the problems faced are related to moral problems. Morals and ethics are also closely related to the character of decency.

Non-formal pasraman activities related to the ethics and morals of pasraman students are Yoga asanas activities. In yoga, it requires several things that Yoga participants should not do, for example, they should not speak harsh words, they should not cheat or be dishonest, they should not be angry. physical and spiritual. Physical and spiritual control is closely related to moral and ethical formation.

Other activities, such as group work in discussing a religious teaching assigned by the pasraman coaches, can also play a role in shaping the morals and ethics of the pasraman students. In the group discussion activities, great attention was paid to ethics in expressing opinions, how to respect the opinions of others, how to defend opinions without offending other people's feelings. A good educational process, of course, aims to make its students smart, but what is more important is how an educational process can achieve the goal of making its students not only smart but also good.

\section{CONCLUSION}

Based on the analysis of the research results as described, there are several roles of non-formal pasramans in shaping the character of Hindu students in Mataram City, namely; (1) Pasraman has a role as a medium for deepening Hindu religious education, (2) Pasraman has a role to prepare and foster achievements in the Hindu religious field, to foster self-confidence, (3) Pasraman has a role to shape and foster religious character, (4) pasraman also has a role to foster a sense of brotherhood and establish communication between students, relating to the habituation of tolerant, clean and disciplined characters, (5) pasraman has a role as a medium for moral and ethical formation, in building the character of politeness in students. These activities are continuously accustomed to pasraman students, it is hoped that over time it will become a culture, and a culture that is practiced repeatedly over a long period of time, it will become a character for someone who carries it out, in the context of this research, pasraman students. 


\section{REFERENCES}

Agus, Cahyono, Cahyanti, Pita Asih Bekti, Widodo, Bambang, Yulia, Yuyun, \& Rochmiyati, Siti. (2020). Cultural-based education of Tamansiswa as a locomotive of Indonesian education system. In Universities as Living Labs for Sustainable Development (pp. 471-486). Springer.

Akbar, Fadly, \& Sulkifli, Sulkifli. (2021). Integrating Character Values in Junior Secondary Student Writing Learning. Jurnal Konsepsi, 10(1), 1-9.

Alief, Kemal, \& Nashruddin, Nashruddin. (2022). Application of Language Politeness in Learning Activities at School. JELITA, 1-11.

Anggreni, Putri. (n.d.). PURNA JATI PASRAMAN POSITION IN IMPROVING HINDU RELIGIOUS EDUCATION ON YOUNG HINDU GENERATION IN NORTH JAKARTA.

Arnyana, Ida Bagus Putu, \& Utami, Ida Ayu Made Istri. (2021). The Implementation of Tri Hita Karana Culture-Based Character Education at Pasraman Budi Pekerti, Kemenuh Village, Bali. 4th International Conference on Innovative Research Across Disciplines (ICIRAD 2021), 279285. Atlantis Press.

Arta, I. Putu Sugih. (2020). Problematic Economic Empowerment and Prospectus of Human Resource Development Through Establishment of Economic Study Program Based on Hindu Cultural. International Journal of Social Sciences and Humanities, 4(3), 75-87.

DIVAYANA, DEWA GEDE HENDRA. (2018). The quality evaluation of school management model based on Balinese local wisdom using weighted product calculation. Journal of Theoretical and Applied Information Technology, 96(19).

Leganger-Krogstad, Heid. (2021). Sustainability in Religious Education. Zur Zukunft Religiöser Bildung in Europa: Festschrift Für Dr. Peter Schreiner.

Mohajan, Haradhan Kumar. (2018). Qualitative research methodology in social sciences and related subjects. Journal of Economic Development, Environment and People, 7(1), 23-48.

Natow, Rebecca S. (2020). The use of triangulation in qualitative studies employing elite interviews. Qualitative Research, 20(2), 160-173.

Rumkel, Lutfi, Sam, Belinda, \& Umanailo, M. Chairul Basrun. (2019). Village head partnership, village consultative body and customary institution in village development. Int. J. Sci. Technol. Res, 8(8), 1058-1063.

Suardana, I. Ketut Putu, Jelantik, Sayu Kadek, Widaswara, Rieka Yulita, \& Harnika, Ni Nyoman. (2021). Preventive Interfaith Marriage Conflicts Through Assistance for Hindu Families Based on Swadharma Grahasta Dormitory in Ngis Hamlet, Buwun Sejati Village, Narmada District, West Lombok Regency. Engagement: Jurnal Pengabdian Kepada Masyarakat, 5(2), 377-396.

Sutriyanti, Ni Komang, \& Dharmawan, I. Made. (2022). Public Satisfaction Survey On Registration Services Of Hindu Religion Education Institutions In Bali Province. Jurnal Penelitian Agama Hindu, 232-243. 
Sutriyanti, Ni Komang, Marsono, Marsono, \& Supandi, I. Nyoman Alit. (2019). Sad Dharma As A Learning Method Of Hindu Religious Education And Character Of 2013 Curriculum In SMP Gurukula Bangli. Vidyottama Sanatana: International Journal of Hindu Science and Religious Studies, 3(1), 109-118.

Suwardani, Ni Putu. (n.d.). EDUCATIONAL VALUE OF THE USE OF ALANGALANG IN HINDU RELIGIOUS CEREMONIES IN BALI.

Wardhani, Evi Thelia Sari1 Parwita Setya, Yuliastanti, Rika, \& Mahardhika, STIE. (n.d.). Plagiarism Checker X Originality Report. 